\title{
The Food of Plankton Organisms. II.
}

\author{
By \\ Marie V. Lebour, D.Sc., \\ Naturalist at the Plymouth Laboratary.
}

With Figures 1-12 in the Text.

LAST year preliminary results on the feeding of some of the commoner plankton organisms were published (1922). Further progress is made this year, more especially on the living animals, chiefly cœlenterates, kept in the plunger jars. The results of these experiments, specially undertaken to find out whether medusæ naturally caught and ate small fishes, answer the question undoubtedly in the affirmative. A large number of the smaller medusæ were kept alive, and most of these were seen to catch and eat fishes. The usual method of catching the food is with the outstretched tentacles, which, drawn out to very fine threads, react when anything living touches them, stinging the prey with their stinging cells; the tentacles then contract and helped by others, and often also by the lips and sides of the umbrella, manage to convey the food to the mouth, from which it reaches the stomach and is digested. A certain amount of selection is apparent, for the tentacles often reject food. Moreover, medusæ of one species do not as a rule eat one another, although taking other species voraciously. If many small fishes are available the smaller crustacea are neglected by many of the medusæ, although these may be taken when other food is scarce. Sagitta bipunctata and Tomopteris helgolandica are popular with nearly all those that can eat fishes. Certain medusæ, e.g. Sarsia tubulosa and S. prolifera, have never been seen to eat anything but crustacea (copepods or decapod larvæ), and fishes have not been seen inside them.

In some cases, although the medusæ were not kept alive, they were taken alive from the tow-nets when eating fishes. It was surprising how the small specimens (hardly a $\mathrm{mm}$. across) could eat fishes much larger than themselves, especially Rathkea octopunctata, which was eating larval Herring and Sprat.

Pleurobrachia pileus will eat fishes eagerly, and has been kept alive and seen to catch them. From the Young Fish Trawl some very large examples were taken by the George Bligh and kindly given me by Mr. 
Clark, which had been feeding abundantly on larval and newly hatched Herring, also on Plaice eggs and newly hatched Plaice.

Sagitta bipunctata is already known to be an enemy of the youn fishes, especially Herring. Many of these feeding on Herring were taken by the Salpa in January, 1923, in the tow-nets and preserved immediately in formalin. These showed the young Herring being taken by the powerful jaws of Sagitta. Many Sagitta were seen with the remains of Herring inside. Further specimens were taken by the George Bligh and given me by Mr. Clark.

Tomopteris helgolandica has been found with fine unicellular food inside, but this year it was seen to eat a Sagitta. More interesting still is the fact that it also eats young Herring. Two specimens from the George Bligh, given me by Mr. Clark in January, 1923, contained distinct remains of these fishes.

The following plankton animals have been found to eat fishes :-

Aurelia aurita (from the Scyphistoma and ephyra up to at least $1 \frac{1}{4}$ inches).

Chrysaora isosceles.

AEquorea sp.

Cosmetira pilosella.

Phialidium sp. (chiefly hemisphericum).

Obelia geniculata.

Laodicea undulata.

Rathkea octopunctata.

Bougainvillea brittanica.

Turris pileata.

Pleurobrachia pileus.

Sagitta bipunctata.

Tomopteris helgolandica.

AURelia aURita Lam.

Last year records were given of the food of Aurelia, showing that the ephyra and young metamorphosed medusæ could eat young fishes. The older stages from over $30 \mathrm{~mm}$. across when caught alive were always empty, except for very small plankton organisms, such as are caught in the medium and coarse tow-nets. It is thus possible that the larger food, such as fish, is only taken in the younger stages (see Lebour, 1922, p. 652). In the paper referred to a young Aurelia was kept alive in the plunger jar, and was still living in April, 1922. After this it continued to eat fishes, but an unfortunate accident, when the plunger was broken, 
cut off one of its long lips. Although this was regenerated the medusa. did not grow, and in July it died. At this time it measured $25 \mathrm{~mm}$., and it grew no larger. During May and June several young Pollack, from 15 to $20 \mathrm{~mm}$. long, were caught and partly eaten, also during the month of July one to three pipe-fishes (Syngnathus acus, ca $25 \mathrm{~mm}$. long) a day were taken, until nearly the end of the month when the medusa died.

Planulæ were taken in May, 1922, from the lips of an adult Aurelia, and introduced into a plunger jar. In September several scyphistomæ were seen to be growing on the plunger. These fed on miscellaneous plankton-copepods, decapod larvæ, larval mollusks, and, more rarely, on young fishes (Cottus). They have not as yet, however (July, 1923), budded off any ephyræ.

In 1923, February to March, young ephyræ from tow-netting taken: in the Sound were reared up to about $20 \mathrm{~mm}$. across, and fed freely on young fishes and other plankton. After metamorphosis their tentacles. were very long and were used in the ordinary way to catch food. As they grew older the tentacles were shorter in comparison with the umbrella.

On April 4th, 1923, a very large number of young Aurelia from about $20 \mathrm{~mm}$. to $25 \mathrm{~mm}$. across were taken in the Young Fish Trawl from between the Victualling Yard and E. Rubble Buoy; 250 were examined for food with the following results :-

\section{6 empty.}

13 contained 1 crab zoëa.

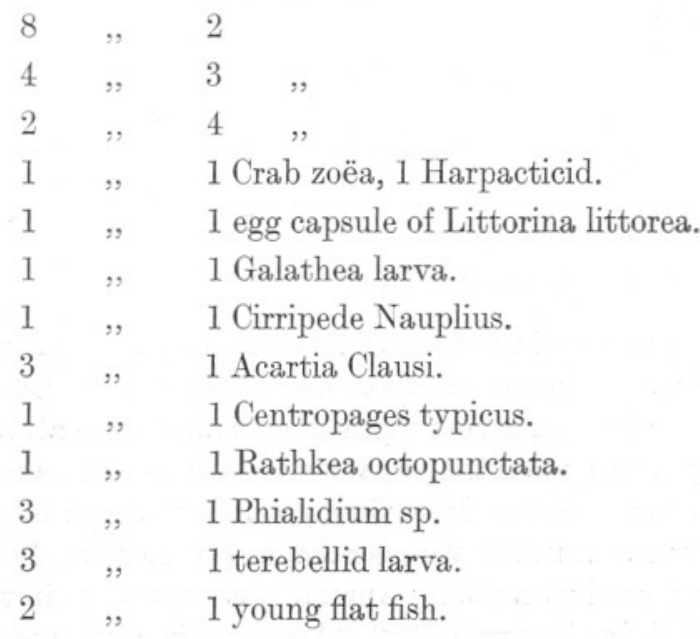

Crab zoëæ were here the commonest food. 
On April 27th a large number of cirripede nauplii were put into the plunger jar with the young Aurelia. These congregated in crowds towards the light and were eaten largely by the Aurelia, which caught them chiefly with their long lips. The lips are armed with tentacles and stinging cells.

Further records of the food of the ephyræ from the tow-nets are as follows :-

Inner Grounds. 1921-1922, March, Crab zoëa in 2, Crab zoëa and. Sagitta in 1, young Herring in 1, young Clupeoid indet. in 1, Sagitta in 1. April, Crab zoëa in 2.

Aurelia, therefore, can eat fishes from its earliest stages up to at least $30 \mathrm{~mm}$. Larger specimens of about $60 \mathrm{~mm}$. have been kept in the plunger jars with fishes, and have not eaten them, and no fishes have as yet been found in those over $30 \mathrm{~mm}$. At all stages they can take the smaller plankton organisms, using ciliary currents (Orton, 1922; Gemmill, 1921; Percival, 1923), and, at any rate in the younger stages, also catch food by means of their tentacles, lappets, or lips of manubrium. We have as yet no evidence of larger food being taken by the adult.

\section{Chrysaora isosceles (L.).}

(Fig. 1)

Last year ephyræ of Chrysaora were recorded which ate young fishes. In May, 1923, a young medusa of this species was brought in from the Sound. It measured ca $25 \mathrm{~mm}$. across, and was in the 8-tentacled stage, the rudiments only of the secondary tentacles being present. The tentacles and lappets that contained the sense organs were a bright chestnut brown; otherwise the medusa was colourless. This was placed in a plunger jar, and fed upon miscellaneous plankton. It would eat young fishes (newly hatched Cottus, Blennius, Lepidogaster, and Gobius), medusæ (Phialidium, Cosmetira, Saphenia, Obelia, but not Turris), Pleurobrachia, Sagitta, Tomopteris, and occasionally crustacea (copepods, larval decapods). Its chief food seemed to be Cœlenterates and Sagitta, although it always took the small fishes when present. All these it would catch one by one with great rapidity with its tentacles, which at first would be greatly extended to their utmost capacity, so as to be many times the diameter of the umbrella. As the food was caught the tentacles contracted and the lips swept off the food, which was collected in a temporary bag made by the lips below the stomach. Sometimes the food reached the stomach, sometimes not, and, as it was usually wholly or partly digested, it is possible that the digestive juices may be poured out on to it. Later, June 6th, another individual, ca $60 \mathrm{~mm}$. across, also from the Sound, was introduced into the same plunger jar. These 
two never attacked one another, although they would eat almost any other medusæ. Two Aurelia, ca $55 \mathrm{~mm}$. across, were put in and were both eaten by the larger Chrysaora; later two more of the same size and a few smaller"were also eaten. Some Pollack (ca $25 \mathrm{~mm}$.), Gunnel

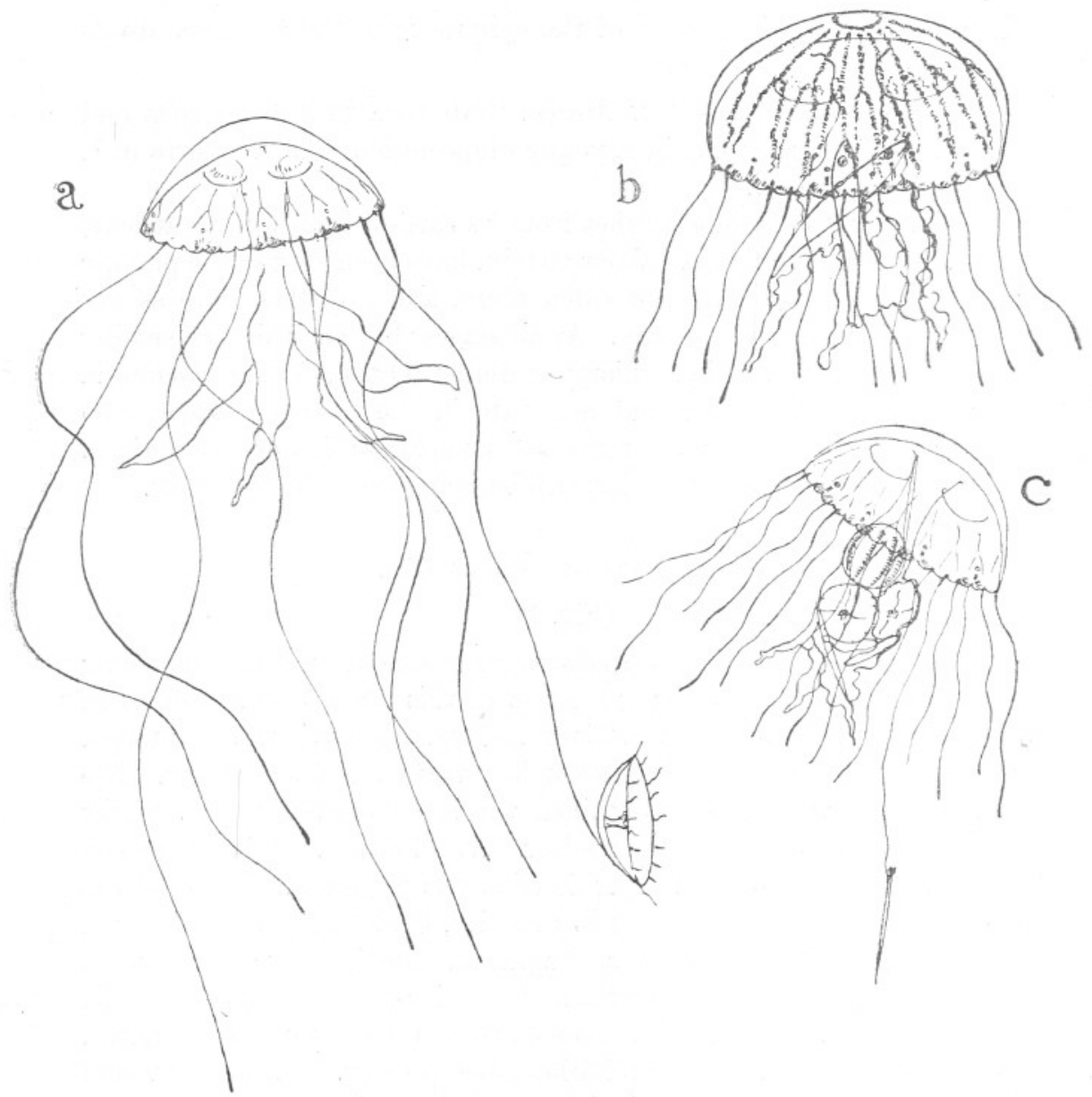

FIG. 1.-Young Chrysaora isosceles feeding in plunger jar.

(a) $25 \mathrm{~mm}$. across, catching a Phialidium.

(b) ca. $60 \mathrm{~mm}$. across, with 2 Pollack inside.

(c) The same as (a), but older, catching a Sagitta and containing Sagitta, Phialidium and Pleurobrachia, June, 1923.

(ca $35 \mathrm{~mm}$.), Gasterosteus (ca $30 \mathrm{~mm}$.), Rockling (ca 25-35 mm.) were caught by both the Chrysaora. These sometimes reached the stomach and were completely digested, more rarely, however, they were enclosed in a temporary bag made by the lips and were apparently 
partially digested, for parts of them were usually ejected. Sometimes as many as four of these larger fishes were taken at one time and caught within a few minutes of one another. At a slightly larger size these fishes were not eaten. Two Rocklings are now in the jar with the larger Chrysaora (July), having been there over a month. These seem to have reached the scaly stage, which may be a deterrent to the medusa.

It is very interesting to watch the medusa feeding rapidly, catching one animal after another until a large pouchful is collected. The tentacles are then contracted for a time whilst digestion goes on. Miss Delap describes the feeding process very accurately (1901). In the Plymouth specimen it was noted that when Crab zoëæ and megalopæ were abundantly present, with medusæ, Pleurobrachia and Sagitta, the three last were immediately eaten and the others left, although if only the crustacea were present a few were eaten, but never so abundantly as the Cœlenterates, Sagitta, and fishes. There is certainly selection here, as is also shown in the way they will not eat one another. Chrysarora is thus an omnivorous feeder, eating chiefly Cœlenterates and Sagitta, but also eating small fishes when available, at any rate in the young stages. Miss Delap's experiences with the same species agree with ours in that medusæ and Pleurobrachia were the favourite food and Sagitta was also frequently taken, but differ in the fact that hers would not eat fishes. The probable explanation is that these were not small or young enough, as a large number of newly hatched and very young fishes were eaten by ours. Moreover, her Chrysaora ephyræ in the process of metamorphosis ate their neighbours of the same species, contrary to our experience with those slightly older. Miss Delap notes that Turris pileata was refused as food, a fact that was also observed with the Plymouth specimens.

One record from the tow-nets, Inner Grounds, April, 1922, shows a specimen of a young form undergoing metamorphosis containing one Crab zoëa and one Hybocodon.

\section{EQUOREA sp.}

(Fig. 2.)

On July 7th, 1922, two young Æquorea, measuring ca $32 \mathrm{~mm}$. across, were brought in from the Sound and placed in a plunger jar. One, after eating many Pleurobrachia, young Lepadogaster and newly hatched blennies (Blennius pholis), was eaten on July 29th by a young Portunus. The other lived until September, usually feeding voraciously and growing to about $40 \mathrm{~mm}$. across. They caught their food in the usual way with their long tentacles, which in a specimen of ca $30 \mathrm{~mm}$. across would be extended to about $180 \mathrm{~mm}$. The neighbouring tentacles and the 


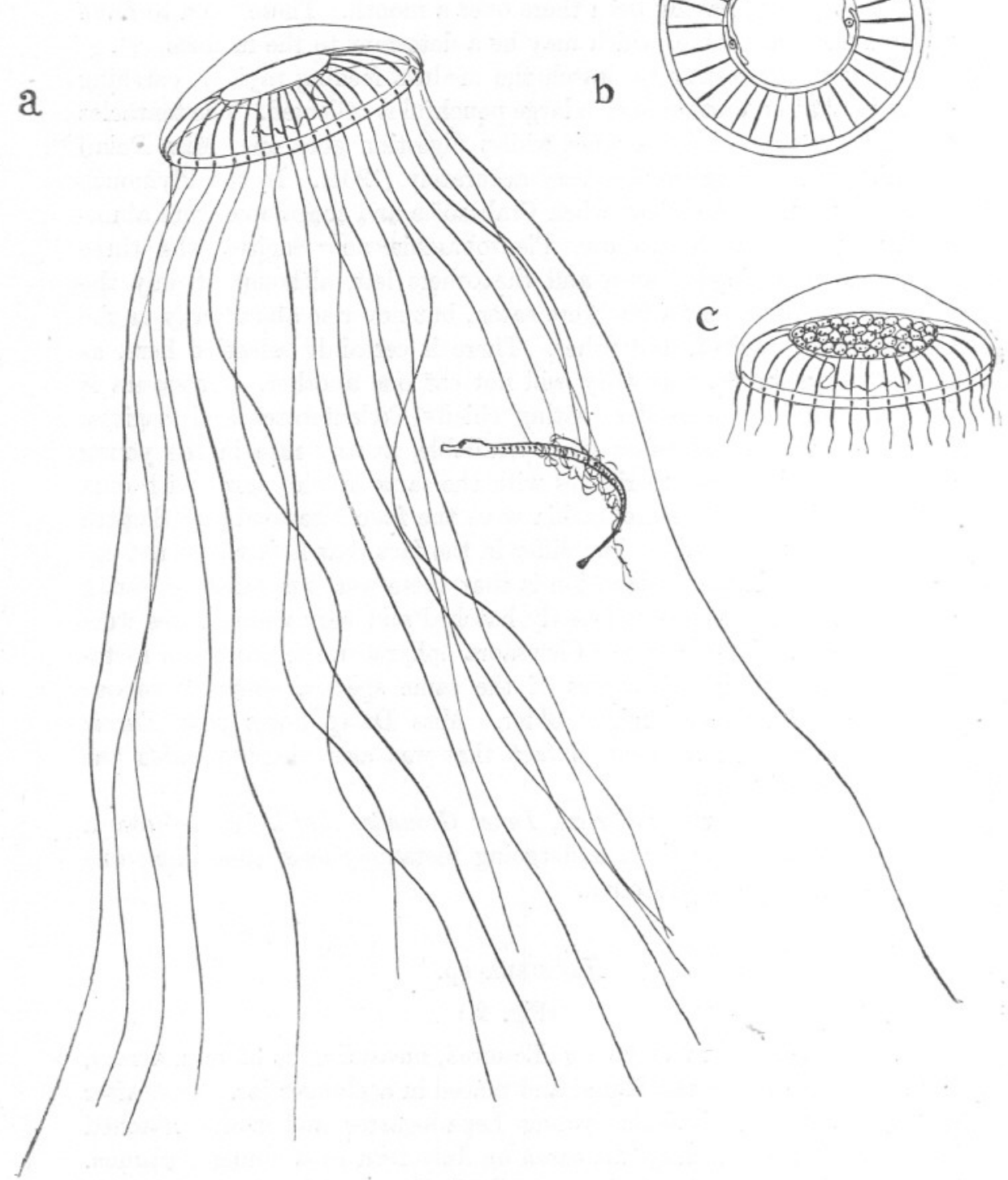

Frg. 2.-Young Æquorea feeding in plunger jar, $32 \mathrm{~mm}$. across.

(a) Catching a pipe-fish.

(b) With 2 pipe-fishes inside stomach.

(c) With stomach full of blennies, July-August, 1922. 


\section{SAPHENIA GRACILIS.}

(Fig. 3, a to c.)

A Gebia larva was recorded last year in a Saphenia. In the summer of 1922 these medusæ were fairly common in the tow-nets, and several were kept alive in the plunger jars. None lived more than a few days, but were active and healthy for that time, and were seen to catch various planktonic animals, including a pipe-fish. The latter, however, after a lengthy struggle escaped. One was caught with a Sagitta inside and another captured a Sagitta in a finger bowl. It was most interesting to watch the method of capture of the food, for Saphenia uses either its manubrium or a tentacle for this purpose. Both of these are armed with similar nematocysts of a long oval shape ; those on the manubrium being smaller and shorter than those on the tentacles. When catching the pipe-fish the manubrium was used, and was so twisted round the fish that a very firm hold was effected. An Obelia was caught with the manubrium, and another specimen was seen to catch a copepod with its tentacle, transfer it to the mouth, and eat it.

A record from the tow-nets, Inner Grounds, July, 1922, shows one specimen containing an Obelia medusa.

\section{Cosmetira pilosella Hartlaub.}

(Fig. 4, a and b.)

This medusa feeds on various animals, including fishes. Last year Crab zoëæ, Caligus, Autolytus, Sagitta, and Lepadogaster were recorded from it. In 1922 several specimens were put in the plunger jar during June and July, but they are not easy to keep alive, and do not live long, possibly because they are delicate and easily injured in the tow-net. On June 29th, one, ca $10 \mathrm{~mm}$. across, caught a young Cottus, ca $6 \mathrm{~mm}$. long, and ate it. One, ca $15 \mathrm{~mm}$. across, caught and ate a Pleurobrachia, ca $7 \mathrm{~mm}$., and the same specimen also caught a young Labrus whilst the Pleurobrachia was in its mouth. When waiting for food the tentacles. are widely outstretched, and soon retracted when the food is caught.

Records from the tow-nets, 1922, are as follows :-

Inner Grounds, June. Pleurobrachia in many, young Callionymus in 1. Outer Grounds, October. Sagitta in 1.

Phialidium sp. (chiefly $P$. hemisphericum Gron.).

Last year's records show Phialidium to be a miscellaneous feeder, esting small fishes to a certain extent. Those in the plunger jars continued to eat young fishes when these were present. 
The following are records from the tow-nets :-

1922-1923, Inner Grounds. January, Sagitta in 2. February, Sprat egg in 1, Oikopleura in 1. March, young Clupeoids in 6, Onos eggs in 2, Oikopleura and Pseudocalanus in 1, Rathkea in 1, Sagitta in 1. April, Sagitta in 5, young Clupeoid in 3, larval Gebia in 2, Centropages typicus in 1, Crab zoëa in 2, Crab zoëa and Rathkea in 3, Pseudocalanus in 1,

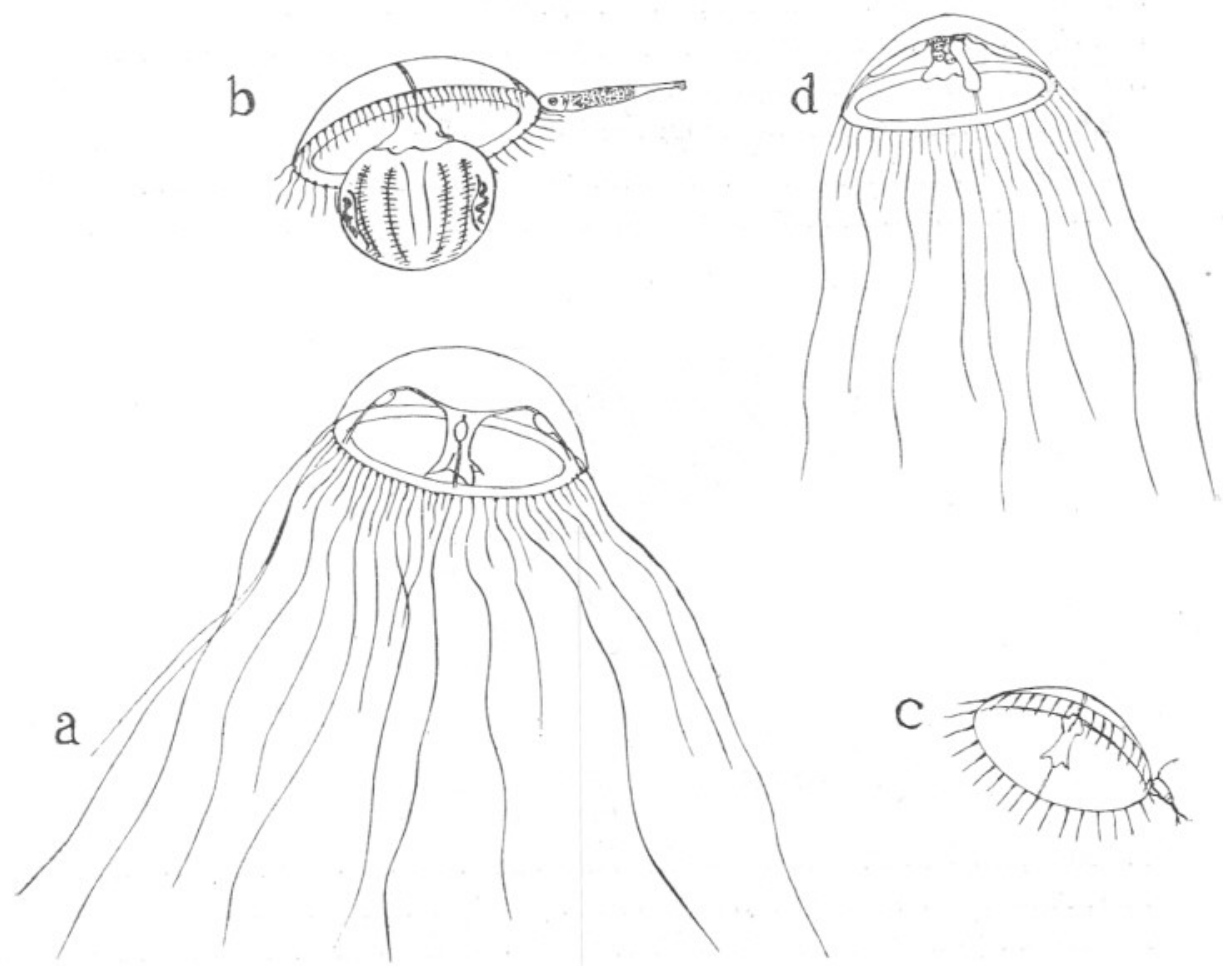

Fra. 4.- (a) and (b) Cosmetira pilosella, ca. $15 \mathrm{~mm}$. across, in plunger jar, 29.6.22.

(a) Ready to feed.

(b) Eating a Pleurobrachia and catching a young Labrus.

(c) Obelia medusa, ca $4 \mathrm{~mm}$., in plunger jar, catching a copepod.

(d) Laodicea undulata, ca $10 \mathrm{~mm}$. across, plunger jar full of young blennies, 29.7.22.

Calanus in 1. June, Calanus in 1, Sagitta in 5, Copepod indet. in 1, Crustacea larvæ in 1, young Cottus in 3, several Pseudocalanus in 1, Obelia medusa in 2, Saphenia in 1. September, Sagitta in many. October, Sagitta in several. November, Sagitta in a few. December, Sagitta in a few.

Outer Grounds. January, Sagitta in 5. March, young Herring in 2, Porcellana larva in 1, Oikopleura in 2. April, Sagitta in 1, young Labrus 
in 1. June, Sagitta in several, Crab zoëa in 2, Calanus in 4. August, Sagitta in 2. November, Sagitta in 1.

As before Sagitta is the most frequent food, but young fishes, Crustacea, and other Cœlenterates are also taken.

Obelia sp. (chiefly O. geniculata Allman).

Many Obelia were kept alive in a plunger jar, but only once was one seen to catch food. This one, ca $4 \mathrm{~mm}$. across, caught a copepod with one of its tentacles (Fig. 4, c). The tentacles are not very contractile, and hardly stretch out at all.

The following records are from the tow-nets :-

1922-1923, Inner Grounds. March, Oikopleura in 2, young Whiting in 1. April, Acartia in 2, young Clupeoid in 1, Hybocodon in 1, Sagitta in

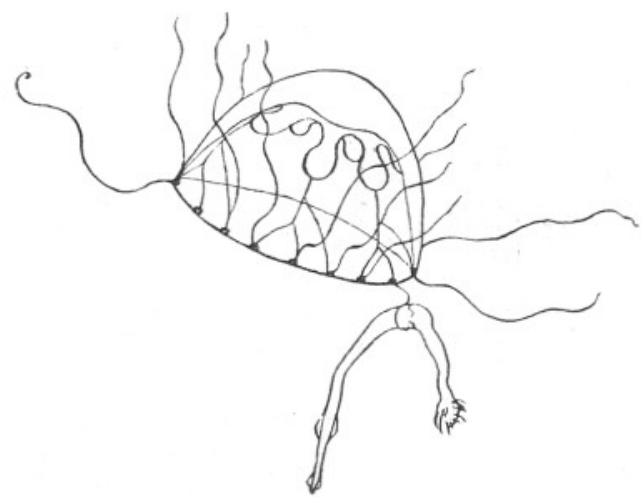

Frg. 5.-Willsia Stellata, ca $4 \mathrm{~mm}$. across, catching a Sagitta, plunger jar, 12.10.22.

1. May, Sagitta in many, Pseudocalanus in 1, Acartia in 3, Gebia larva in 1, Annelid larva in 1, Crab zoëa in 1, young Whiting in 1, Oikopleura in several, young Callionymus in 1, Obelia medusa in 1, Calanus in 1. July, young Callionymus in 2, Pseudocalanus in 1, Calanus in 1. October, Sagitta in several, Crab zoëa in 1. November, Sagitta in 1. December, Pseudocolanus in a few.

Outer Grounds. April, Sagitta in 1. May, Sagitta in many, Oikopleura in several. October, Sagitta in 1, Crab zoëa in 1.

Again the records show Obelia to be a miscellaneous feeder, feeding much on Sagitta and small crustacea, and occasionally on young fishes.

Laodicea undulata Forbes \& Goodsir.

$$
\text { (=L. cruciata A. Ag.) }
$$

Many last year had eaten Calanus. One (ca $10 \mathrm{~mm}$. acróss), July 29, 22 , was kept alive for one day only in a plunger jar. It caught and ate 
several young blennies, Blennius pholis, catching them quickly one after the other with its outstretched tentacles, until the stomach was full (Fig. 4, d).

\section{Willsia stellata Forbes.}

This is rare in the tow-nets. One specimen (ca $4 \mathrm{~mm}$. across) placed in the plunger jar, caught and ate a Sagitta (Fig. 5).

\section{Rathkea octopunctata Hæckel.}

(Fig. 6.)

Although these medusæ were difficult to keep alive in the plunger jars and were never seen to feed there, they were often taken from the townets whilst feeding, or would feed when freshly brought in and placed in a glass bowl. Small fishes were frequently seen inside them, especially Herring and Sprat. These were usually partly digested and well inside the mouth. In one case, however (Fig. 6, a), a specimen, ca $1 \mathrm{~mm}$. across, had caught a Herring many times its own size, and, as this was much too big to get into the mouth, it was sucking at it, clinging on firmly by its labial tentacles, which are armed with tufts of nematocysts. The stream of fluid food could be seen running up the mouth and stomach and down the canals. In another (Fig. 6, b), which had medusa buds on the manubrium, one of the buds, less than $1 \mathrm{~mm}$. across, had caught a young Sprat with its lips, and in another a Sprat was sticking out of the mouth half digested (Fig. 6, c). Similar instances could be multiplied. Often the bell was completely everted whilst feeding. A specimen taken alive from the tow-net and placed in a glass bowl caught and ate an Oikopleura in this way. The whole animal was finally taken in by a succession of gulps (Fig. 6, d).

The following are records from the tow-nets :-

1922-1923, Inner Grounds. January, Sagitta in 1. February, Crab zoëa in 1, Crab egg in 1, Oikopleura in 3, Copepods in 2, young Sprat in 2, young Herring in 1. March, young Clupeoids in 4, 2 Pseudocalanus in 1, Sagitta in 3, Oikopleura in 1. April, young Clupeoid in 1, Phialidium in 1, Crab zoëa in 3, copepods indet. in many, larval Gebia in 1. May, Pseudocalanus in 3, young Clupeoid in 1, Gebia larva in 1, Acartia in 1 .

Outer Grounds, March. Oikopleura in 2, young Clupeoid in 1, Sagitta in 1 , Oikopleura in 1.

These records show that fishes are frequently taken, although Crustacea and Sagitta are the commonest food. 


\section{Bougainvillea bRittanica Forbes.}

This medusa was difficult to keep alive, although it lived in the plunger jar a few days and fed on copepods. A very young specimen, ca $1 \mathrm{~mm}$.

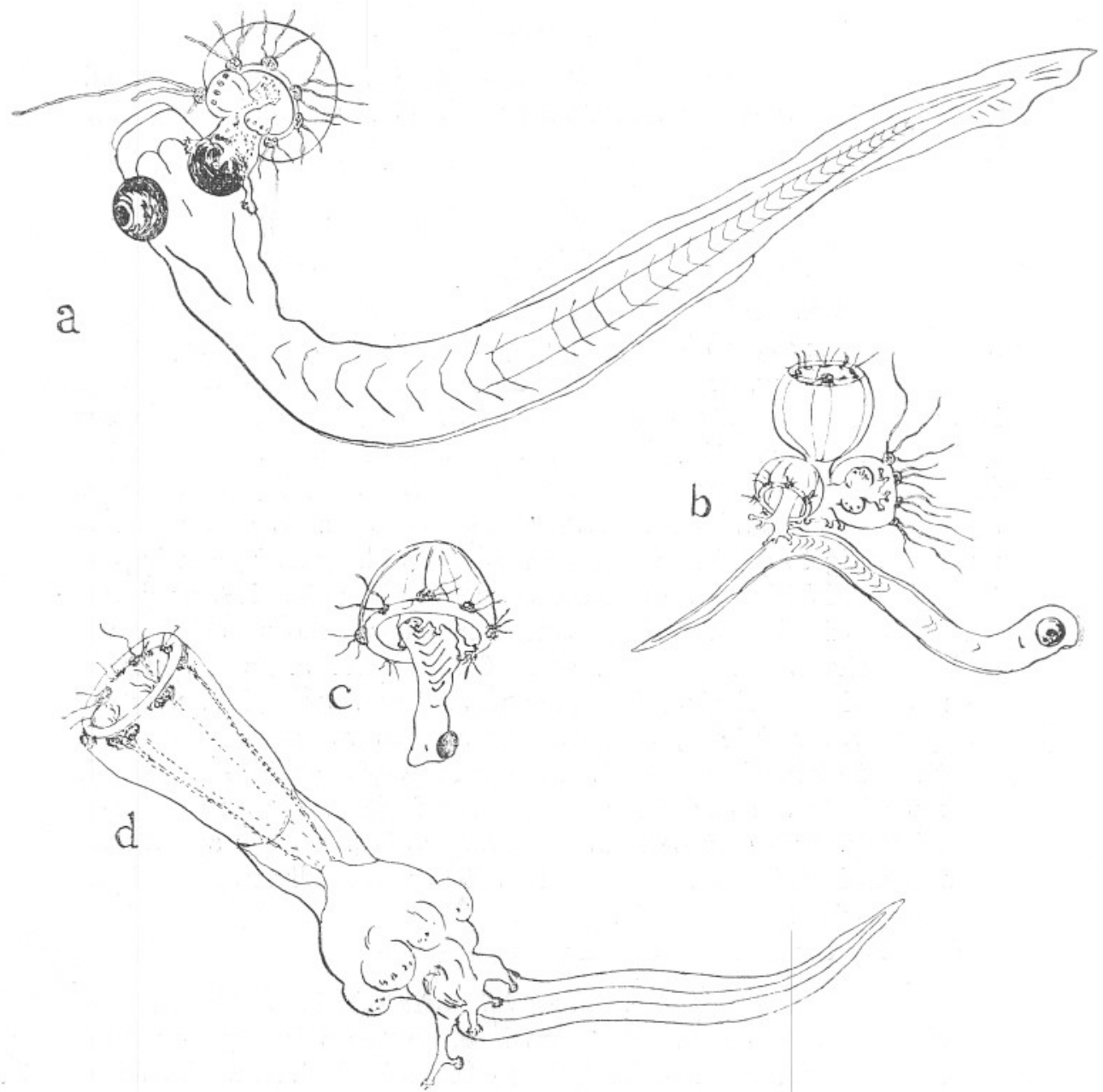

FIG. 6.-Rathkea octopunctata, up to $1 \mathrm{~mm}$. across, feeding on Sprat and Oikopleura, Tow-nets, 22.2.23.

(a) Eating Herring.

(b) Eating Sprat.

(c) Sprat half digested.

(d) Specimen everted, eating Oikopleura.

across, was taken from the tow-net, having caught a young Sand-eel, Ammodytes tobianus, which it was holding in its mouth with its lips. tightly clinging to it (Fig. 7). 
The following records are from the tow-nets :-

1922, Inner Grounds. February, Young Ammodytes in 1. August, Podon in 1. November, Temora in 1.

\section{TƯris pileata (Forskål).}

Records were given last year of the food of this species in the plunger jar. It is omnivorous and highly voracious, often swallowing food

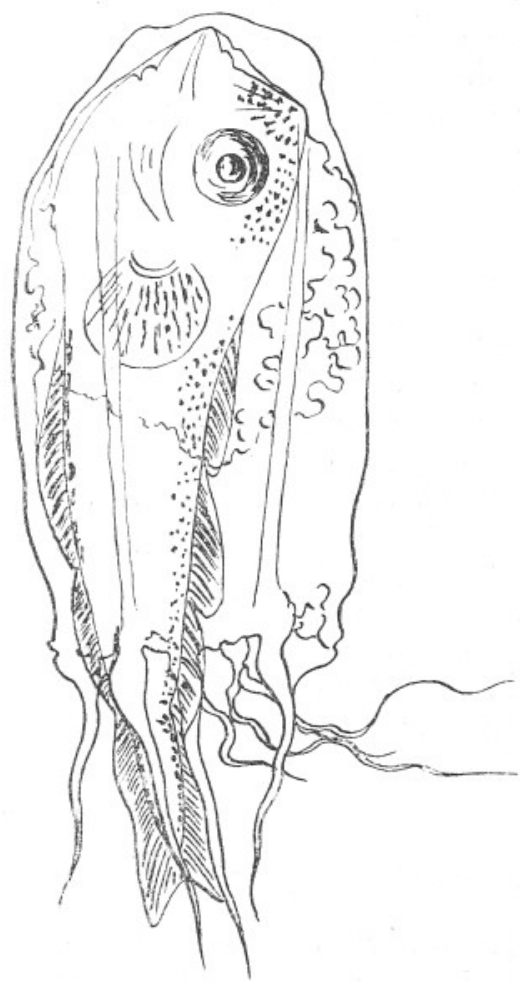

FIG. 8.-Turris pileata, $25 \mathrm{~mm}$. long, containing young Whiting, Y.F.T., Station L6, 27.6.22.

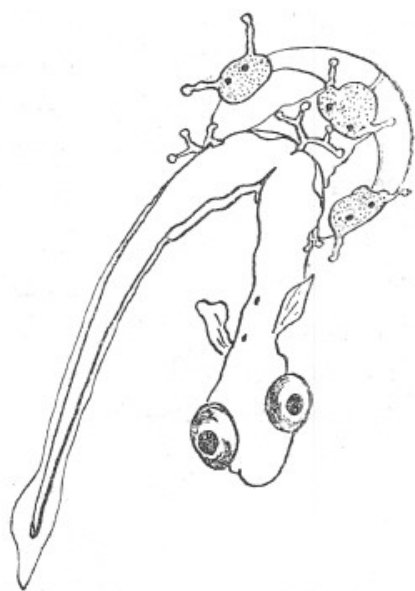

FIG. 7.-Bougainvillea britannica, ca $1 \mathrm{~mm}$, across, eating a young Sand-eel, Tow-net, RameEddystone, 12.2.23.

much larger than itself. It is a dangerous species to keep in an Aquarium, as it will eat almost anything and apparently is not much eaten by other animals. Two specimens kindly given me by Mr. Clark contained young Whiting longer than the medusa itself. These are engulfed whole, stretching the stomach wall considerably (Fig. 8). One from the Young Fish Trawl, Station 26, lat. $50^{\circ} 06^{\prime}$ N., long. $4^{\circ} 20^{\prime}$ W., 27.6.22, had eaten a Whiting, $25 \mathrm{~mm}$. long, which a'most completely filled its body (Fig. 8); 
the other from Station L4, lat. $50^{\circ} 15^{\prime}$ N., long. $4^{\circ} 13^{\prime}$ W., 9.6.22, in a similar way contained a Whiting $17 \mathrm{~mm}$. long.

The following records are from the tow-nets :-

1922, Inner Grounds, August. Many Calanus in 5, Acartia in 1, Crab zoëa and Calanus in several, Crab zoëa in 3, Porcellana larvæ in 1.

Outer Grounds. May, Young Callionymus in 1. June, Calanus in several, young Cottus in 1. July, Crab zoëa in several, Calanus in 1, Porcellana larva in 1, Crab zoëa and Porcellana larva in 1. August, Calanus in 3, many Crab zoëæ and Calanus in 1, Gebia larva in 1, Anomalocera, Crab zoëa, and Gebia larva in 1, Crab zoëa, Podon, Poecilochætus larva in 1. November, decapod larvæ and Calanus in 1.

\section{Stomotoca dinema L. Ag.}

In July-August, 1922, a few were kept alive for several days, but only once was one seen to feed when a specimen, ca $3.5 \mathrm{~mm}$. across, ate a Saphenia, ca $7 \mathrm{~mm}$. across (Fig. 3, d). The two tentacles were greatly extended and used for balancing whilst it was eating.

One from the tow-nets contained an Obelia medusa. Last year's records show medusæ, Calanus, and Sagitta as food. No fishes have been seen in it.

Sarsia tubulosa (Sars) and S. Prolifera Forbes. Sarsia tubulosa was shown last year to feed on copepods, and previously Mr. E. T. Browne had reared it on these. S. prolifera in October contained Corycæus in 1, Harpacticid and Acartia in 1. The genus thus appears to be mainly a copepod feeder. No fishes have been seen in them.

\section{Steenstrupia RUBRA Forbes.}

Several medusæ kept alive in the plunger jar caught and ate copepods. These were caught by the long tentacle and transferred to the mouth. It was never seen to eat fishes, but previous tow-net records show fish eggs as food and a Clupeoid and Ammodyte is recorded in the following list of food from the tow-nets :-

1922, Inner Grounds. March, Young Ammodytes in 2, Calanus in 1, Crab zoëa in 1, Pseudocalanus in 1. April, young Clupeoid in 1, copepods in 1. May, copepods indet. in 1, Pseudocalanus and Acartia in many, Calanus in several, Temora in 1, Pseudocalanus in 1.

Outer Grounds, April. Pseudocalanus in several, Sagitta in 1, egg indet. in 1. 


\section{CTENOPHORA.}

\section{Pleurobrachia pileus (Fab.).}

Pleurobrachia is known to eat young fishes amongst the large variety of food which it takes. Several were kept alive in the plunger jars from June to August, 1922, ranging from $3 \mathrm{~mm}$. to $10 \mathrm{~mm}$. long.

These ate other Pleurobrachia, Calanus, pipe-fishes (Syngnathus, ca $25 \mathrm{~mm}$. long), and Sagitta. In one case a Pleurobrachia, ca $10 \mathrm{~mm}$. long, caught a pipe-fish, ca $25 \mathrm{~mm}$. long. After playing it for half an hour the fish escaped, carrying most of the tentacle with it (Fig. 9). The heads of the pipe-fishes eaten are usually ejected. A Pleurobrachia,

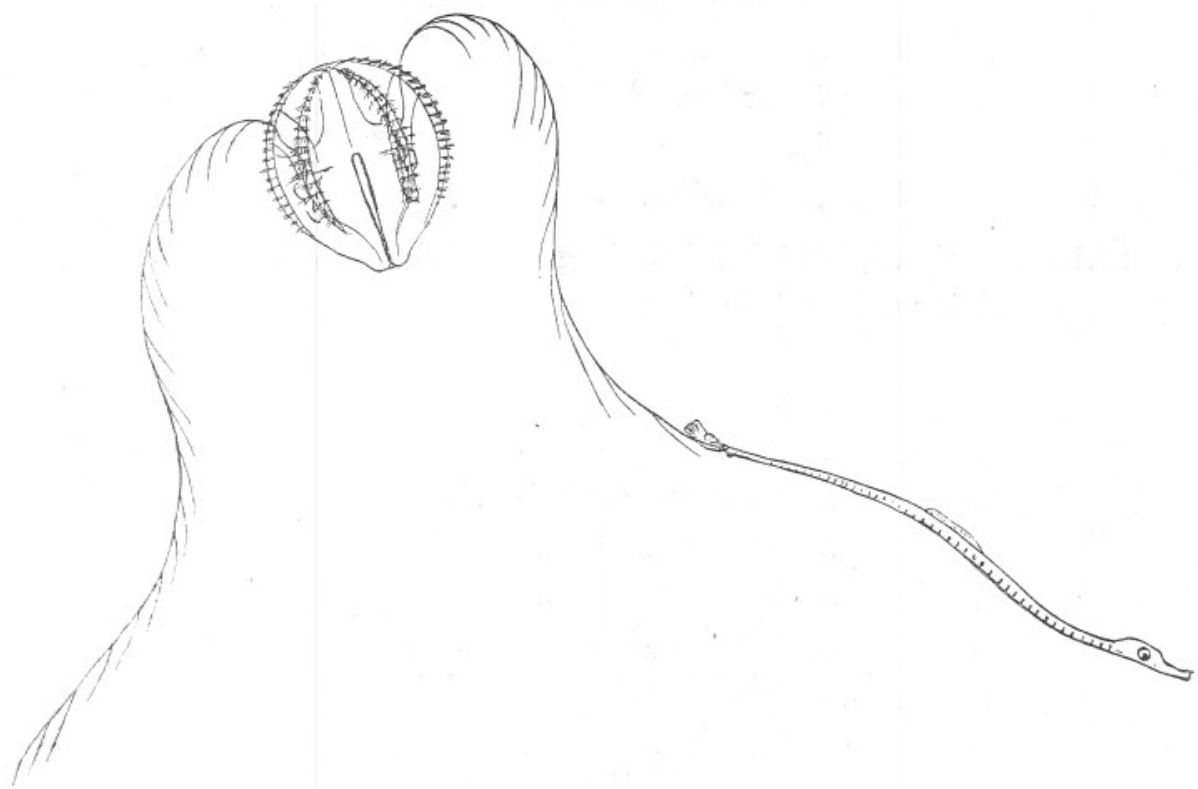

Fra. 9.-Pleurobrachia pileus, ca $10 \mathrm{~mm}$., eatching a pipe-fish, plunger jar, 29.6.22.

ca $4 \mathrm{~mm}$. long, caught and partly digested a Gobius Ruthensparri, over $10 \mathrm{~mm}$. long, which it could not get entirely into its mouth.

When strong and well the Pleurobrachia has its tentacles with the pinnæ fully outstretched and catches the food as it passes by, immediate reaction taking place at the touch of the prey, which is entangled in the contracted tentacle and conveyed to the mouth and stomach.

Mr. Clark has kindly given me specimens from the George Bligh cruise in the eastern part of the Channel, January, 1923, where they were very large, ca $18 \mathrm{~mm}$. long. Some of these had eaten Plaice eggs and young Plaice. Others were full of young Herring, newly hatched or only 
a few days old. In these cases the mouth and stomach were enormously extended, the aperture being nearly half the diameter of the body (Fig. 10). The following are the records :-

George Bligh cruise, LIII, 1923.

27.1.23, Station 3, lat. $51^{\circ} 15^{\prime}$ N., long. $1^{\circ} 51^{\prime}$ E., surface, 1 p.m.

Several Pleurobrachia containing Plaice eggs.

27.1.23, Station 5, lat. $51^{\circ} 5^{\prime}$ N., long. $1^{\circ} 51^{\prime}$ E., bottom 30 f., 8 p.m.

Large Pleurobrachia (18-20 mm.).

3 containing Plaice eggs ( 2 in 1,1 in 2 ).

$2 \quad$, 1 Herring and much indiscriminate remains.

$1 \quad, \quad 2 \quad, \quad$, " ,

$1 \quad$ " several Herring.

$1 \quad, \quad 1$ mysid.

$1 \quad, \quad 1 \quad,, 1$ sagitta.

27.1.23, Station 6, lat. $51^{\circ} 15^{\prime}$ N., long. $1^{\circ} 51^{\prime}$ E., surface, 11 p.m. 2 containing at least 4 Herring.

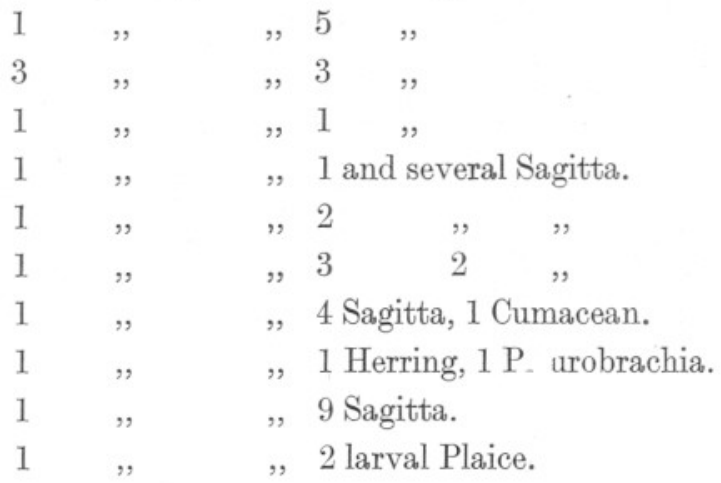

27.1.23, Station 6, bottom, 20 f., 11 p.m.

1 containing 1 Euphausiid.

$\begin{array}{lll}1 & , & \text { skin of , } \\ 1 & \text { " } & \text { Temora, Oikopleura. } \\ 1 & \text { " } & \text { larval Herring. } \\ 3 & \text { " } & \text { copepods. } \\ 3 & \text { " } & \text { Plaice eggs. }\end{array}$

29.1.23, Station 12 , lat. $49^{\circ} 5^{\prime}$ N., long $0^{\circ} 10^{\prime}$ E., bottom, 12.5 a.m.

Many Pleurobrachia containing Herring larvæ. It is interesting that these records are chiefly at night or early morning. 
The following records are from the tow-nets :-

1922, Inner Grounds. June, Remains of young fish indet. in 2, Sagitta in 1. July, young Labrus in 1, young Cottus in 2, Crab zoëa in 1, Gebia larva in 1, Pseudocalanus in 1. August, Centropages in 1.

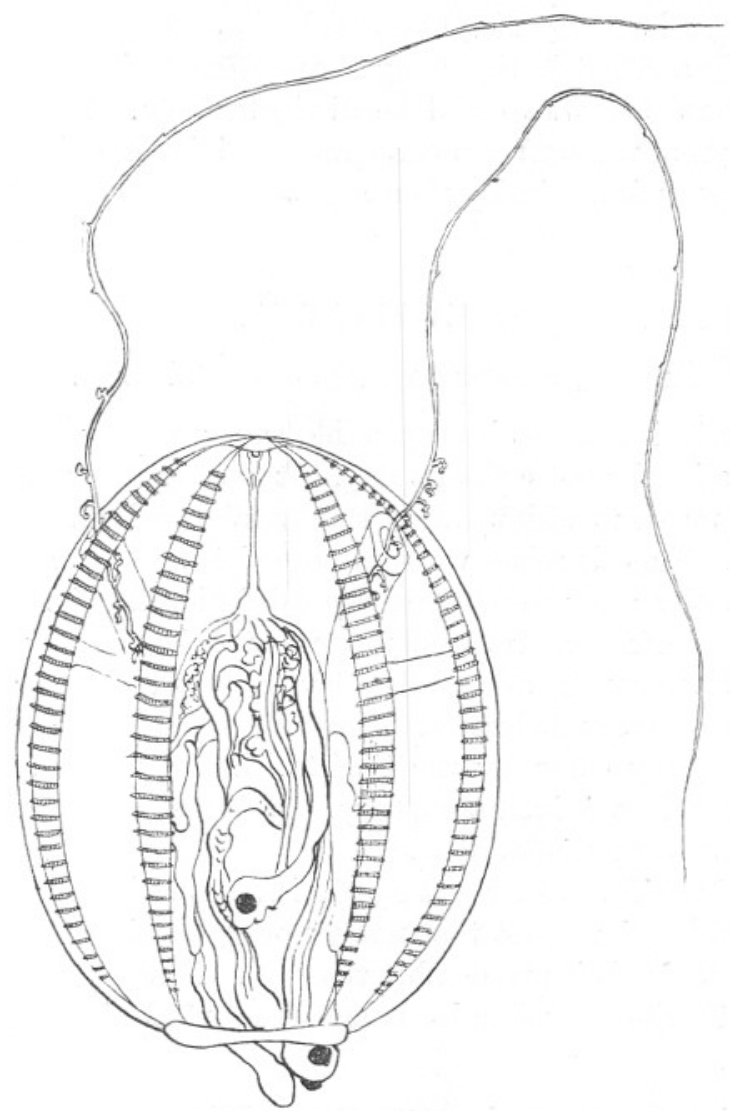

FIG. 10.-Pleurobrachia pileus, $18 \mathrm{~mm}$. long, full of young Herring, Y.F.T., George Bligh, Voyage LIII, Station 6, 11 p.m., preserved in formalin, 27.1.23.

Outer Grounds, June. Gebia larva in 2, Calanus in 1, Crab zoëa in 1, Sagitta in 1, Bipinnaria in 1, young fish indet. in 1 .

\section{Beroë Cucumis Fab.}

Beroë was taken several times in 1922 with Bolina and Pleurobrachia. It was often seen to be full of either one or the other or both. Sometimes Calanus was seen inside it. This agrees with last year's records. Mr. 
Percival, of Leeds University, tells me that last spring, off Robin Hood's Bay on the Yorkshire coast, a number of Beroë taken contained diatoms, probably Coscinodiscus.

\section{Bolina infundibulum Fab.}

Two or three large tow-net hauls of Bolina were brought in during June and July and put in the plunger jars. Some of these were young, and their lateral tentacles could be distinctly seen. They lived some time, keeping near the surface and apparently living on minute life there. Nothing was ever found inside them.

\section{CHÆTOGNATHA.}

\section{SagitTa BIPUnCtata (Quoy \& Gaimard).}

Unfortunately it has not been possible as yet to keep Sagitta in the plunger jars alive for more than a day. It was, however, taken several times in the tow-nets whilst eating the larval Herrings, and preserved immediately. These it seizes with its powerful jaws at any part of the body, and usually gets the whole of the fish inside it (Fig. 11). Sagitta is a miscellaneous feeder. Its usual food most of the year being copepods, other Sagitta and young fishes. The latter seem to be specially taken in January and early February, when the young Herring are newly hatched and freely eaten by the Sagitta. A large proportion of the specimens taken in any haul are empty, but so many are eating Herring that much damage must be done.

In some of the hauls of the Young Fish Trawl in the George Bligh cruise Mr. Clark pointed out that many young Herring were cut in two or beheaded and this is presumably the work of Sagitta. Many Sagitta were eating Herrings in these hauls and these were kindly given to me by Mr. Clark.

The following records are from the George Bligh cruise, LIII, January, 1923 :-

28.1.23, Station 7, lat. $50^{\circ} 31^{\prime}$ N., long. $0^{\circ} 48^{\prime}$ E., surface, 5 a.m.

Many Herring beheaded, probably by Sagitta.

29.1.23, Station 12 , lat. $49^{\circ} 50^{\prime}$ N., long. $0^{\circ} 10^{\prime}$ E., bottom, 19 f., 1.30 a.m.

Many Sagitta eating Herring larvæ.

30.1.23, Station 18 , lat. $50^{\circ} 00^{\prime}$ N., long. $1^{\circ} 25^{\prime}$ W., surface, 3.30 a.m.

Several Sagitta eating Herring larvæ, some grasping them, some. with the larvæ inside. 
30.1.23, Station 18 , lat. $50^{\circ} 14^{\prime}$ N., long. $2^{\circ} 7^{\prime}$ W., bottom, 27 f., 11.50

a.m. Several Sagitta eating Herring larvæ.

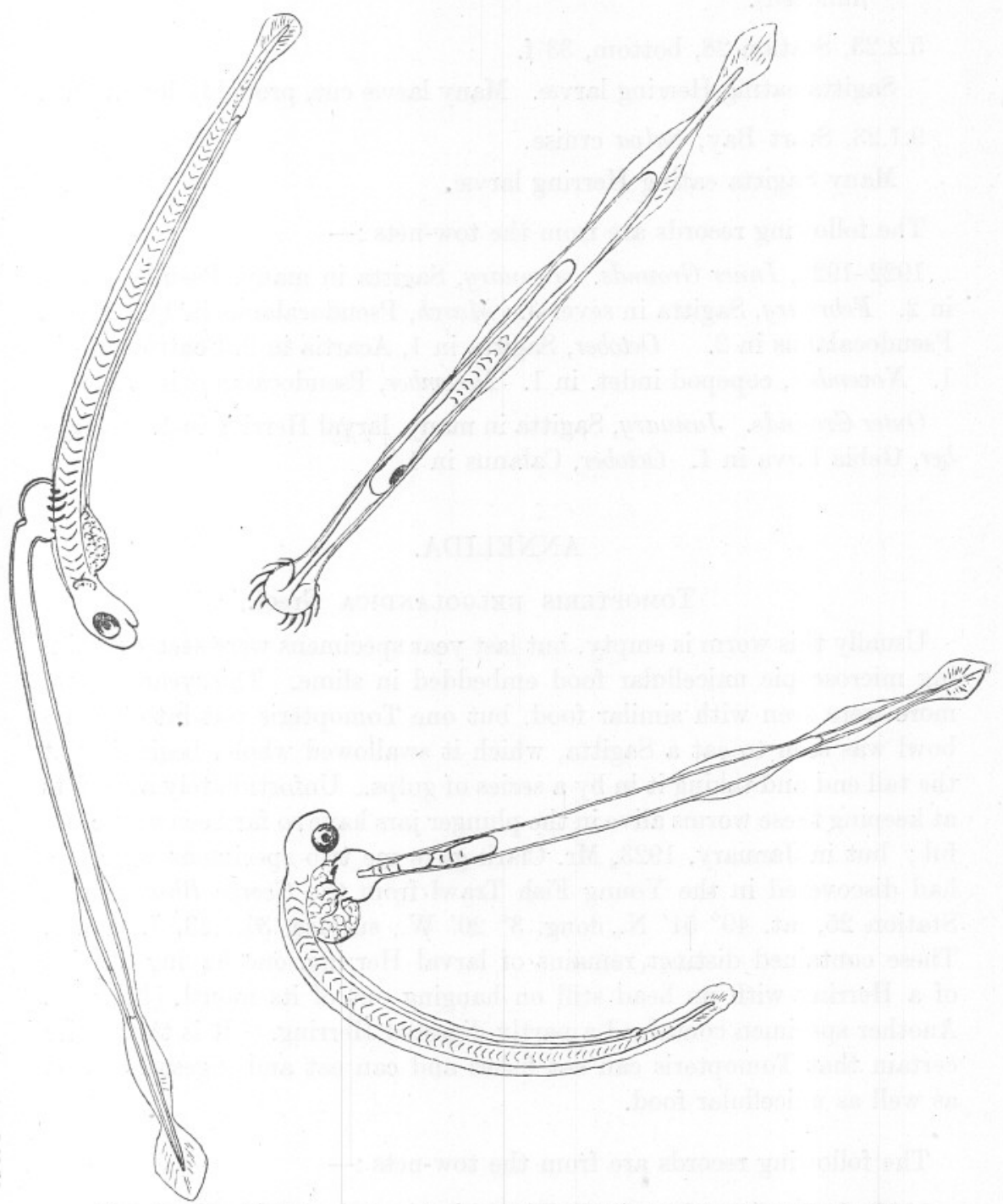

Fra. 11. Sagitta bipunctata, eating young Herring, 6.5-7 mm. long, Tow-nets, Start Bay, January, 1923.

31.1.23 Station 25 , lat. $49^{\circ} 51^{\prime}$ N., long. $2^{\circ} 58^{\prime}$ W., surface, 7.45 a.m. Several Sagitta eating Herring larvæ.

31.1.23, Station 25, bottom, 39 f. Several Sagitta eating Herring larvæ. 
5.2 .23 , Station 28 , lat. $50^{\circ}, 1^{\prime}$ N., long. $1^{\circ} 48^{\prime}$ W., surface, 8.40 p.m.

Sagitta eating Herring larvæ (about 6 with food out of several hundred).

5.2.23, Station 28, bottom, $33 \mathrm{f}$.

Sagitta eating Herring larvæ. Many larvæ cut, probably by Sagitta.

9.1.23, Start Bay, Salpa cruise.

Many Sagitta eating Herring larvæ.

The following records are from the tow-nets :-

1922-1923, Inner Grounds. January, Sagitta in many, Pseudocalanus in 2. February, Sagitta in several. March, Pseudocalanus in 14. April, Pseudocalanus in $2 . \quad$ October, Sagitta in 1, Acartia in 2, Centropages in 1. November, copepod indet. in 1. December, Pseudocalanus in a few.

Outer Grounds. January, Sagitta in many, larval Herring in 1. September, Gebia larva in 1. October, Calanus in 1.

\section{ANNELIDA.}

\section{Tomopteris helgolandica Greef.}

Usually this worm is empty, but last year specimens were seen containing microscopic unicellular food embedded in slime. This year several more were seen with similar food, but one Tomopteris put into a glass bowl was seen to eat a Sagitta, which it swallowed whole, beginning at the tail end and taking it in by a series of gulps. Unfortunately attempts at keeping these worms alive in the plunger jars have so far been unsuccess ful ; but in January, 1923, Mr. Clark gave me two specimens which he had discovered in the Young Fish Trawl from the George Bligh cruise, Station 25, lat. $49^{\circ} 51^{\prime}$ N., long. $3^{\circ} 20^{\prime}$ W., surface, 31.1.23, 7.30 a.m. These contained distinct remains of larval Herring, one having a third of a Herring with its head still on hanging out of its mouth (Fig. 12). Another specimen contained a partly digested Herring. It is thus quite certain that Tomopteris can eat fishes and can eat and digest Metazoa as well as unicellular food.

The following records are from the tow-nets :-

1922, Inner Grounds. April, Nitzschia closterium, N. seriata, Thalassiothrix nitzschioides, Paralia sulcata, Chætoceros sp., Streptotheca thamensis in 1. July, eggs, indet., much Skeletonema, Nitzschia closterium in 1. September, Sagitta in 1. October, green flagellates in 1.

Outer Grounds, November. Bits of diatoms, Nitzschia, and others in 1. Many Tomopteris from the tow-nets were empty. 
These notes on the larger plankton organisms give us a good idea of their method of feeding and their food in general. All these extremely

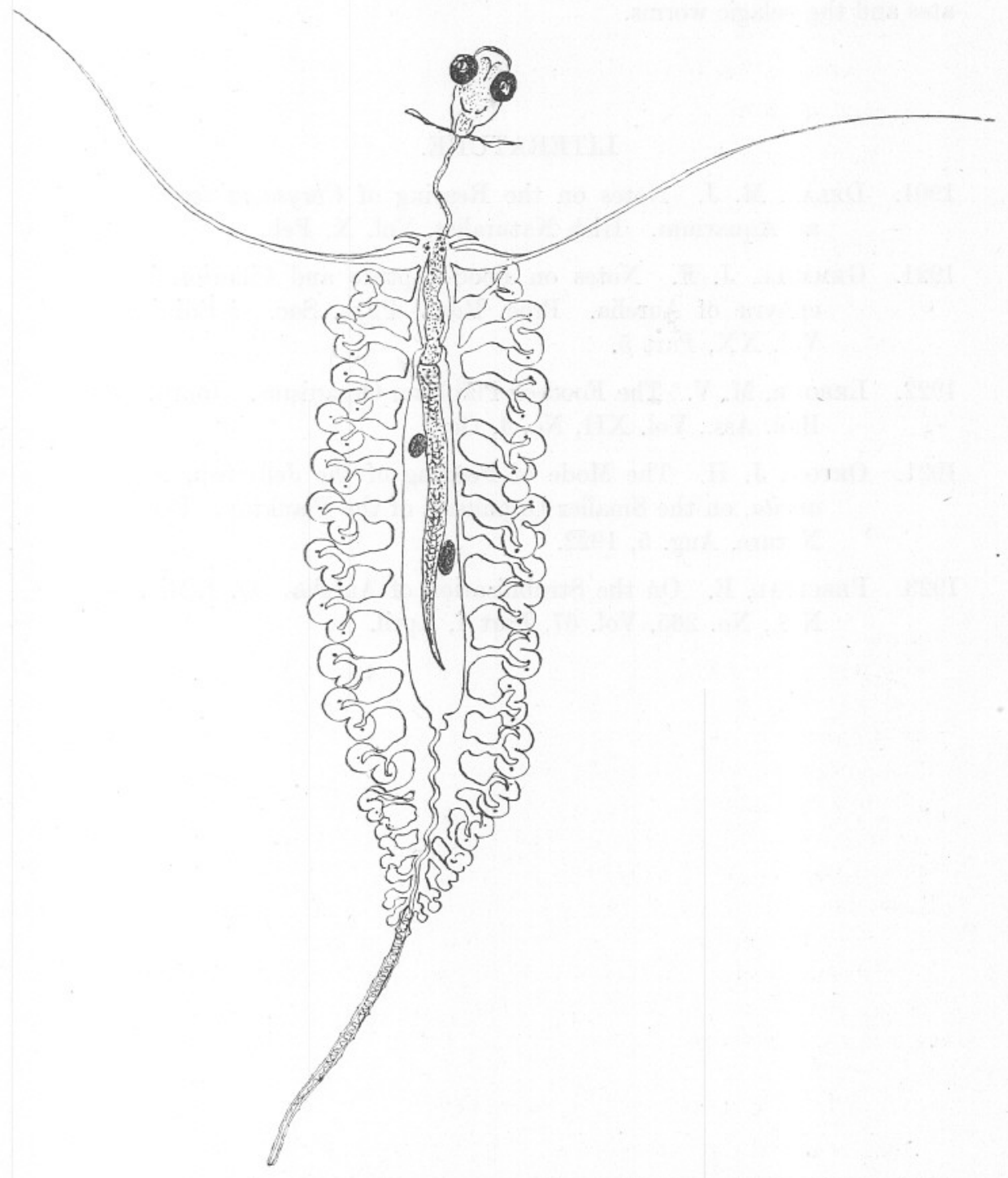

FIG. 12.-Tomopteris helgolandica, containing larval Herrings, Y.F.T., George Bligh. One Herring is hanging out of the mouth, the second is represented by 2 eyes and part of the body inside.

transparent and delicate creatures are very voracious, and in those regions where the plankton is thickly distributed the animals are con- 
M. V. LEBOUR.

tinually preying upon one another. Newly hatched and very young fishes can have little chance against all these enemies, for, as is shown, they must form part of the natural food of most of the common Cœlenterates and the pelagic worms.

\section{LITERATURE.}

1901. Delap, M. J. Notes on the Rearing of Chrysaora isosceles in an Aquarium. Irish Naturalist, Vol. X, Feb.

1921. Gemmill, J. F. Notes on Food-Capture and Ciliation in the ephyræ of Aurelia. Proc. Royal Phys. Soc. of Edinburgh, Vol. XX, Part 5.

1922. Lebour, M. V. The Food of Plankton Organisms. Journ. Mar. Biol. Ass., Vol. XII, No. 4, Oct.

1921. Orton, J. H. The Mode of Feeding of the Jelly-fish, Aurelia aurita, on the Smaller Organisms of the Plankton. Letter to. Nature, Aug. 5, 1922.

1923. Percival, E. On the Strobilisation of Aurelia. Q. J. Mic. Sci., N.S., No. 265, Vol. 67, Part I, April. 